\title{
HUBUNGAN FAKTOR PREDISPOSING, REINFORCING DAN ENABLING PADA PEKERJA SANDBLASTING DI PT X
}

\author{
Aditya Reino Susanto, Denny Ardyanto \\ Departemen Keselamatan dan Kesehatan Kerja \\ Fakultas Kesehatan Masyarakat Universitas Airlangga \\ E-mail: adityareinosusanto@gmail.com
}

\begin{abstract}
Sandblasting process contained some hazards such as shock effect on workers, who may pose a danger to himself or worker in the vicinity, the wound on the surface of the workers skin or eyes, and silicosis. The aim of this study was analyze correlation between predisposing, reinforcing, and enabling factors with PPE usage behavior on worker in sandblasting division at PT X. This study is an observational analytic with cross sectional design. Data of knowledge, attitudes, perception, motivation, the role of co-workers, the role of supervisor, HSE promotion, HSE training, availability of PPE and HSE regulations obtained from interviews to all 11 people who worked at sandblasting division of PT X. PPE usage of $90,9 \%$ workers are in the safe category. Results analysis with contingency coefficient was known that motivation factor has a value at 0.707 , the factor of co-workers role has a value at 0.459 , and the factor of knowledge, attitudes, supervisors role, as well as HSE training has a value at 0.100, while the perception factor, HSE promotion, availability of PPE, and HSE regulations showed that $100 \%$ of workers are in the good category. Motivational factors have a strong correlation with the PPE usage behavior, co-workers role factors have correlation in the medium category, the factors of knowledge, attitudes, role of supervisor, HSE training has a very weak correlation to the PPE usage behavior, meanwhile perception, HSE promotion, availability of PPE, and HSE regulations factors of all workers are included in good categories.
\end{abstract}

Keywords: predisposing, reinforcing, enabling, sandblasting, personal protective equipment

\begin{abstract}
ABSTRAK
Sandblasting proses mengandung risiko bahaya seperti efek kejut pada pekerja yang dapat menimbulkan bahaya bagi dirinya atau pekerja di sekitarnya, luka pada permukaan kulit atau mata, dan penumpukan debu silika pada paru-paru. Penelitian ini dilakukan untuk menganalisis hubungan antara predisposing, reinforcing, dan enabling factors dengan perilaku pemakaian APD pada pekerja bagian sandblasting di PT X. Penelitian ini merupakan penelitian analitik yang bersifat observasional dengan rancang bangun cross sectional. Data pengetahuan, sikap, persepsi, motivasi, peran rekan kerja, peran pengawas, promosi K3, pelatihan K3, ketersediaan APD dan peraturan K3 diperoleh dari wawancara kepada semua pekerja sandblasting sebanyak 11 orang yang bekerja di PT X. Pemakaian APD pada 90.09\% pekerja termasuk dalam kategori baik. Hasil analisis dengan coefficient contingency diketahui bahwa faktor motivasi memiliki value sebesar 0,707, faktor peran rekan kerja memiliki value sebesar 0,459, dan faktor pengetahuan, sikap, peran pengawas, serta pelatihan K3 memiliki value sebesar 0,100, sedangkan faktor persepsi, promosi K3, ketersediaan APD, dan peraturan K3 sebesar 100\% pekerja berada dalam kategori baik. Faktor motivasi memiliki hubungan yang kuat dengan perilaku pemakaian APD, faktor peran kerja memiliki hubungan dalam kategori sedang, faktor pengetahuan, sikap, peran pengawas, pelatihan K3 memiliki hubungan sangat lemah terhadap perilaku pemakaian APD, faktor persepsi, promosi $\mathrm{K} 3$, ketersediaan APD, dan peraturan K3 seluruh pekerja termasuk dalam kategori baik.
\end{abstract}

Kata kunci: predisposing, reinforcing, enabling, sandblasting, alat pelindung diri

\section{PENDAHULUAN}

Sandblasting adalah suatu proses pengerjaan logam di mana permukaan logam dibuat menjadi kasar dan rata dengan derajat kekasaran serta laju pengikisan tertentu, dengan kebutuhan dengan cara menembakkan bahan abrasive ke permukaan logam dengan tekanan tertentu. Proses sandblasting bertujuan agar permukaan logam menjadi kasar, sehingga cat atau bahan pelapis lain dapat menempel pada permukaan logam dengan baik, tidak mudah terkelupas, dan terhindar dari korosi.

Berdasarkan SK Presiden No. 22 tahun 1993, disebutkan berbagai macam penyakit yang timbul karena hubungan kerja, salah satunya adalah pneumoconiosis. Silikosis adalah penyakit yang paling penting dari golongan pneumoconiosis. Tahun 1996, silikosis dilaporkan terjadi pada 60 orang dari 1072 pekerja pabrik mobil. Risiko penyakit ini 
meningkat seiring dengan lama pajanan terhadap partikel silika, sebanyak $12 \%$ pekerja dengan masa kerja lebih dari 30 tahun menderita silikosis (Susanto, 2011).

Upaya terakhir untuk mencegah terjadinya penyakit akibat kerja pada pekerja sandblasting adalah dengan menghindari pajanan pekerja dengan debu silika. Beberapa cara dapat dilakukan, antara lain mengganti bahan yang berbahaya dengan bahan yang kurang atau tidak berbahaya, membatasi bahan pajanan, menggunakan ventilasi keluar, dan pemakaian APD pada pekerja (Ikhsan, 2002).

Kegagalan memakai alat pelindung diri dengan benar merupakan salah satu contoh dari perilaku tidak aman yang dapat memicu terjadinya insiden dalam bentuk hubungan langsung antara pekerja dengan sumber bahaya, dalam hal ini adalah debu silika (BIrd dan Germain, 1992).

Perilaku pemakaian Alat Pelindung Diri ini dapat dianalisis menggunakan teori Precede. Teori ini menyatakan bahwa secara umum, perilaku dipengaruhi oleh beberapa faktor, seperti faktor predisposing, reinforcing dan enabling (Green, 1991).

Predisposing yang merupakan pemicu berasal dari diri manusia yang meliputi pengetahuan, persepsi, motivasi, dan sikap. Reinforcing, meliputi peran rekan kerja dan peran pengawas sebagai faktor yang mendukung tindakan keselamatan kerja, dan faktor enabling yang meliputi promosi K3, ketersediaan Alat Pelindung Diri, pelatihan K3, dan peraturan keselamatan sebagai kemampuan dari sumber daya yang diperlukan untuk membentuk perilaku pekerja.

Sampai saat penelitian ini dilakukan, PT $\mathrm{X}$ belum memiliki data mengenai silikosis atau penyakit akibat kerja lainnya. Menurut observasi awal, peneliti menemukan bahwa banyak pekerja sandblasting yang tidak memakai Alat Pelindung Diri sesuai dengan bahaya yang ada di tempat kerjanya. Menurut pihak manajemen, mereka sudah menyediakan Alat Pelindung Diri yang sesuai dengan bahaya yang ada di tempat kerja mereka, seperti masker dan safety shoes, akan tetapi salah satu pekerja mengatakan bahwa Alat Pelindung Diri yang tersedia sudah tidak layak pakai, dan mereka sudah mengajukan untuk mengganti namun belum ada jawaban dari pihak manajemen. Saat proses wawancara, ditemukan bahwa salah satu pekerja belum memahami mengenai peraturan keselamatan yang diberikan oleh pihak manajemen. Selain itu, ada juga pekerja yang menyatakan bahwa media promosi keselamatan dalam bentuk mading yang dipakai perusahaan tidak memotivasi mereka untuk berperilaku aman.

Penelitian ini secara umum ditujukan untuk menganalisis hubungan antara faktor Predisposing, Reinforcing, dan Enabling dengan perilaku pemakaian APD pada pekerja bagian sandblasting di PT X, dan secara khusus bertujuan untuk mengidentifikasi faktor predisposing, antara lain pengetahuan, sikap, persepsi dan motivasi pekerja. Faktor reinforcing, antara lain peran rekan pekerja dan perilaku pengawas. Faktor enabling, antara lain promosi K3, ketersediaan APD, Pelatihan K3, dan Peraturan K3, mengidentifikasi perilaku aman dalam bentuk pemakaian APD pada pekerja.

Menganalisis hubungan antara faktor predisposing, antara lain pengetahuan, sikap, persepsi dan motivasi pekerja dengan perilaku pemakaian APD pada pekerja bagian Sand Blasting di PT X, menganalisis hubungan antara faktor reinforcing, antara lain peran rekan pekerja dan perilaku pengawas dengan perilaku pemakaian APD pada pekerja bagian Sand Blasting di PT X, menganalisis hubungan antara faktor enabling, antara lain promosi K3, ketersediaan APD, Pelatihan K3, dan Peraturan K3 dengan perilaku pemakaian APD pada pekerja bagian sandblasting di PT X.

\section{METODE}

Mengacu pada metode pengolahan data, maka penelitian yang dilakukan termasuk penelitian observasional karena peneliti hanya melakukan observasi pada sampel penelitian dan tidak memberikan perlakuan pada subjek penelitian.

Berdasarkan metode pengolahan dan analisis data, maka penelitian ini tergolong dalam penelitian deskriptif karena peneliti hanya melihat dan menggambarkan penyebab dari terjadinya substandard practice pada pekerja sandblasting di PT X berdasarkan teori precede dari Lawrence Green (1991)

Berdasarkan dimensi waktu, maka penelitian ini merupakan Cross sectional study, karena data yang dikumpulkan pada satu kurun waktu saja, yaitu pada saat melaksanakan praktek penelitian di lapangan.

Penelitian ini diterapkan dan menggunakan total populasi pada pekerja sandblasting di area kerja PT $\mathrm{X}$ yang berjumlah 11 orang dan dilaksanakan di PT $\mathrm{X}$ pada bulan Januari-Februari 2014.

Variabel penelitian ini adalah faktor predisposing yang terdiri dari pengetahuan, sikap, 
persepsi dan motivasi, faktor reinforcing yang terdiri dari peran rekan kerja dan peran pengawas, faktor enabling yang terdiri dari promosi K3, Ketersediaan APD, Pelatihan K3 dan peraturan K3, serta perilaku aman dalam bentuk pemakaian APD pada pekerja sandblasting di PT X.

Jenis data yang digunakan merupakan data primer yang diperoleh dari hasil wawancara pada pekerja sandblasting dengan pedoman kuesioner dan juga hasil observasi peneliti selama penelitian berlangsung, dan data sekunder dari gambaran umum perusahaan mengenai peraturan dan kebijakan $\mathrm{K} 3$, serta data penunjang yang lain yang diperoleh dari bagian Kesehatan dan Keselamatan Kerja PT $\mathrm{X}$.

Instrumen yang digunakan dalam penelitian adalah lembar kuesioner sebagai pedoman wawancara dan lembar observasi. Isi kuesioner merupakan adopsi dari kuesioner yang telah dibuat oleh Geer LA, Curbow BA, Anna DH, Lees PSJ, dan Buckley TJ (2012) yang diterjemahkan. Pengukuran variabel dalam kuesioner ini menggunakan skala Guttman, di mana responden diminta menunjukkan tingkat persetujuannya dengan jawaban ya atau tidak yang mempunyai nilai jawaban 1 untuk jawaban benar dan 0 untuk jawaban salah. Lembar observasi yang digunakan berisi tabel checklist mengenai Alat Pelindung Diri yang digunakan oleh pekerja sandblasting selama proses blasting berlangsung.

Analisis data dalam penelitian ini menggunakan analisis univariat untuk melihat distribusi frekuensi dan analisis persentase setiap variabel penelitian, kemudian dilanjutkan dengan menggunakan analisis tabulasi silang atau crosstabs dan analisis bivariat untuk menganalisis kuat hubungan antara variabel bebas dengan variabel terikat dengan menggunakan uji contingency coefficient.

\section{HASIL}

Pada predisposing, reinforcing dan enabling factors, skor 1 akan didapatkan apabila pekerja sandblasting dapat menjawab pertanyaan dengan benar dan mendapatkan skor 0 bila pekerja sandblasting salah menjawab pertanyaan tersebut.

Hasil penelitian mendapatkan bahwa 63,6\% pekerja sandblasting menjawab K3 adalah kegiatan untuk melindungi semua orang di tempat kerja, sedangkan $36.4 \%$ responden menjawab bahwa K3 hanya merupakan program agar pekerjaan berjalan lancar tanpa ada hambatan sedikit pun agar proses kerja dapat berjalan terus.
Hasil kuesioner predisposing factors pada pekerja sandblasting PT X juga mendapatkan bahwa $63,3 \%$ pekerja sandblasting menjawab bahwa kecelakaan kerja adalah kejadian yang tidak diinginkan, dapat mengakibatkan cedera, dan kerusakan di tempat kerja, sedangkan 36,4\% lainnya menjawab bahwa kecelakaan kerja adalah kejadian yang merugikan pekerja dan perusahaan, dan mereka menegaskan bahwa pekerja harus mendapatkan ganti rugi. Perilaku tidak aman menurut 90,9\% pekerja adalah perilaku yang bila dilakukan berisiko besar untuk terjadinya kecelakaan, sedangkan 9,1\% responden menjawab bahwa perilaku tidak aman adalah perilaku yang bila dilakukan akan mendapatkan sanksi dan teguran dari mandor dan perusahaan.

Berdasarkan wawancara pada pekerja sandblasting di PT X juga mendapatkan hasil bahwa pada waktu awal pekerja sandblasting bekerja disini, $100 \%$ responden menjawab bahwa mereka mendapatkan safety induction mengenai lingkungan kerja dan peraturan yang terkait dengan pekerjaan mereka oleh departemen HSE di PT X. Selain itu, sebanyak $90,9 \%$ responden selalu mengikuti pelatihan yang diberikan oleh perusahaan, sedangkan $9,1 \%$ responden pernah tidak mengikuti karena sedang tidak enak badan, $81,8 \%$ pekerja mengaku bekerja pada bidang yang sama sebelum bekerja di PT X, sedangkan $18,2 \%$ pekerja menjawab sebelum ini memiliki profesi yang berbeda, seperti satpam atau helper untuk welder.

Berdasarkan hasil penelitian mengenai faktor pengetahuan, didapatkan bahwa $90,9 \%$ pekerja memiliki pengetahuan dalam kategori baik, sedangkan hanya $9,1 \%$ pekerja yang memiliki pengetahuan dalam kategori buruk. Hal ini terjadi akibat kurangnya pemahaman dasar dari para pekerja pada konsep Keselamatan dan Kesehatan Kerja.

Pada penelitian mengenai sikap pemakaian APD pada pekerja sandblasting di PT X juga mendapatkan hasil bahwa $81,8 \%$ pekerja menjawab tidak pernah sekalipun tidak memakai APD, sedangkan 18,2\% pekerja lainnya mengaku pernah tidak memakai APD dikarenakan APD sudah tidak layak pakai, dan ada juga yang menjawab bahwa Alat Pelindung Dirinya sudah tidak layak pakai, telah dilaporkan pada pengawas, namun belum diberikan sampai saat penelitian ini berlangsung.

Hasil penelitian mengenai faktor sikap juga mendapatkan $90,9 \%$ pekerja merasa terlindungi dengan APD yang mereka pakai, sedangkan $9,1 \%$ pekerja menjawab bahwa hood respirator 
dirasa kurang tebal, sehingga belum memberikan perlindungan yang maksimal. Selain itu $63,6 \%$ responden merasa tidak aman pada saat bekerja tidak mengikuti SOP sedangkan 36,4\% lainnya merasa aman dikarenakan mereka tidak mengalami cedera apabila tidak bekerja sesuai dengan SOP.

Kuesioner pada faktor sikap mengidentifikasi bahwa 9,1\% responden menjawab bahwa tanpa memakai APD, dirinya terbukti tidak mengalami cidera, oleh karena itu responden masih merasa aman pada saat tidak memakai salah satu APD, sedangkan $90,9 \%$ yang lain merasa takut terjadi kecelakaan pada saat tidak memakai Alat Pelindung Diri.

Pada hasil penelitian mengenai faktor sikap didapatkan 90,9\% pekerja sandblasting mempunyai sikap dalam kategori baik dan 9,1\% memiliki sikap dalam kategori buruk. Berdasarkan tingginya kategori baik dari pekerja, dapat terlihat bahwa mayoritas pekerja memiliki sikap yang mendukung terjadinya perilaku aman di lingkungan kerja mereka.

Berdasarkan distribusi jawaban pekerja sandblasting mengenai faktor persepsi didapatkan bahwa seluruh pekerja sandblasting pada PT X merasa pengawas sangat peduli dengan keselamatan mereka. Seluruh pekerja juga merasa bahwa pelatihan yang diberikan kepada mereka sudah sesuai dengan pekerjaan mereka di PT X dan pekerja sandblasting juga merasa bahwa APD yang mereka pakai telah memberikan perlindungan yang maksimal. Selain itu, semua pekerja sandblasting di PT X juga merasa cukup puas dengan pelatihan yang diberikan oleh perusahaan dan seluruh pekerja juga merasa mengerti mengenai isi materi yang diberikan saat pelatihan. Faktor persepsi para pekerja sandblasting di PT X mengenai pelatihan, APD dan peran pengawas termasuk sangat baik secara keseluruhan.

Berdasarkan distribusi jawaban pada faktor motivasi pekerja, didapatkan $81,8 \%$ pekerja sandblasting mengikuti program safety meeting setiap seminggu sekali pada hari rabu, sedangkan $18,2 \%$ menyatakan tidak selalu mengikuti safety meeting pada hari rabu karena alasan bosan. Pada saat akan melakukan pekerjaan baru, 90,9\% pekerja sandblasting mengikuti pengarahan, sedangkan $9,1 \%$ lainnya menyatakan tidak mengikuti karena menurut pekerja tersebut sudah mengerti dengan apa yang akan dikerjakan. Pada kuesioner mengenai motivasi pekerja, juga didapatkan bahwa $72,7 \%$ pekerja merasa tidak pernah mendapatkan hadiah pada saat berperilaku aman, akan tetapi $27,3 \%$ sisanya mengaku pernah mendapatkan hadiah berupa snack pada saat berperilaku aman.

Distribusi jawaban kuesioner pekerja sandblasting pada faktor motivasi mendapatkan $90,9 \%$ pekerja menjawab tidak pernah mendapatkan hukuman, karena saat melakukan tindakan tersebut tidak terlihat oleh pengawas, namun pada $9,1 \%$ responden mengaku pernah mendapatkan hukuman sebesar Rp. 100.000,00 karena kedapatan merokok dan tidak memakai safety shoes di tempat kerjanya. Sebanyak 18,2\% pekerja juga pernah melakukan pekerjaan tidak sesuai SOP karena merasa tidak nyaman, akan tetapi $81,8 \%$ menyatakan tidak pernah, karena takut akan terjadi kecelakaan. Pada hasil wawancara pada faktor motivasi juga didapatkan $90,8 \%$ pekerja menyatakan sama sekali tidak pernah melakukan tindakan berbahaya untuk menghemat waktu, karena mereka mendapatkan uang lembur, sehingga mereka merasa tidak perlu melakukan tindakan tersebut. Seluruh pekerja sandblasting pada PT X juga menjawab bahwa mandor atau pengawas mereka selalu memberikan contoh berperilaku aman seperti tidak merokok dan selalu memakai APD di tempat kerjanya.

Berdasarkan hasil penelitian pada faktor motivasi pekerja didapatkan bahwa $90,9 \%$ pekerja sandblasting mempunyai motivasi dalam kategori baik, sedangkan $9,1 \%$ lainnya memiliki motivasi dalam kategori yang buruk. Hal ini dapat terjadi akibat kurangnya motivasi untuk berpartisipasi dalam program keselamatan di perusahaan. Secara keseluruhan, dapat disimpulkan bahwa pekerja sandblasting di PT X memiliki predisposing factors dalam kategori baik.

Berdasarkan hasil penelitian pada faktor peran rekan pekerja yang ada pada lampiran, didapatkan hasil bahwa seluruh pekerja sandblasting di PT X merasa bahwa rekan kerja memotivasi mereka untuk selalu berperilaku aman.

Pada wawancara mengenai peran rekan pekerja, sebanyak $81,8 \%$ pekerja pernah diingatkan oleh rekan kerjanya saat tidak memakai APD, sedangkan $18,2 \%$ pekerja mengaku tidak pernah diingatkan oleh rekan kerjanya, malah cenderung diabaikan pada saat mereka melakukan tindakan tidak aman. Pada wawancara mengenai faktor rekan pekerja ini juga didapatkan bahwa 27,3\% mengaku bahwa mereka dibiarkan saat tidak bekerja sesuai SOP, sedangkan $72,7 \%$ pekerja sandblasting pernah diingatkan dan ditegur oleh rekan kerjanya saat tidak bekerja sesuai SOP. 
Selain itu, hasil wawancara pada pekerja juga mendapatkan bahwa 18,2\% responden menjawab rekan kerjanya pernah melakukan tindakan yang mengganggu konsentrasi responden saat bekerja, seperti tertidur pada saat mereka berada di dalam sandblasting chamber, hal ini sangat berbahaya, khususnya pada chamber gudang 12, karena chamber pada gudang tersebut sistem ventilasinya mengalami kerusakan, dan setiap 10 menit sekali chamber harus dibuka agar debu biji besi tidak terlalu pekat di dalam. Karena rekan kerjanya tertidur, maka proses pekerjaan pekerja sandblasting ini sedikit terganggu. Selain itu juga ada yang mengaku bahwa rekan kerjanya ada yang sering menyanyi di tempat kerja. Karena menurut pekerja ini suaranya tidak terlalu bagus, maka hal ini dirasa sangat mengganggu konsentrasi pekerja lainnya, akan tetapi $81,8 \%$ pekerja lainnya merasa tidak pernah terganggu oleh kegiatan rekan pekerja lainnya.

Hasil penelitian faktor peran rekan kerja pada pekerja sandblasting di PT X sebesar 72,7\% memiliki hubungan dalam kategori baik dengan rekan kerja mereka, sedangkan $27,3 \%$ sisanya memiliki kategori hubungan rekan kerja yang buruk. Hubungan antara rekan pekerja sandblasting di PT $\mathrm{X}$ ini dapat dilihat dari pengertian antara pekerja dan kepedulian mereka dengan rekan kerjanya.

Berdasarkan hasil penelitian pada faktor peran pengawas, ditemukan sebesar $90,9 \%$ pekerja sandblasting mengaku bahwa pengawas selalu ada di tempat kerja pada saat mereka bekerja. Khususnya di gudang wenang sakti, karena pengawas mereka juga ikut bekerja, sedangkan 9,1\% merasa bahwa pengawas pernah sesekali tidak ada pada saat mereka bekerja. Seluruh pekerja menjawab bahwa pengawas selalu menegur apabila pekerja sandblasting ditemukan salah atau tidak memakai APD dan bekerja tidak sesuai SOP oleh pengawasnya.

Pada hasil wawancara dengan pekerja sandblasting, didapatkan hasil bahwa $81,8 \%$ pekerja mengaku bahwa pengawas memberi sanksi seperti denda setelah peringatan 2 kali, dan sanksi pulang pada saat bekerja apabila setelah didenda masih melakukan tindakan tidak aman, sedangkan 18,2\% lainnya menjawab bahwa mereka terkadang tidak didenda oleh pengawas, karena pengawas tidak tahu bahwa mereka berbuat tindakan tidak aman. Hasil wawancara pada pekerja juga mendapatkan hasil bahwa sebanyak $18,2 \%$ pekerja mengaku pernah sesekali mendapatkan pujian dari mandor karena perilaku mereka, akan tetapi $81.8 \%$ pekerja merasa tidak pernah sama sekali dipuji oleh pengawas pada saat mereka berperilaku aman.

Pada hasil wawancara mengenai peran pengawas pada pihak manajemen, didapatkan hasil bahwa program teguran terhadap perilaku tidak aman telah dilaksanakan oleh PT X namun program tersebut hanya terfokus pada pekerja yang tidak memakai salah satu APD saja, dan tidak melihat pada tata cara dan ketidaksesuaian pemakaian APD tersebut.

Berdasarkan penelitian mengenai faktor peran pengawas didapatkan hasil bahwa $90,9 \%$ pekerja sandblasting merasa bahwa peranan pengawas mereka sudah baik, dan hanya $9,1 \%$ pekerja yang memiliki kategori peran pengawas yang buruk. Secara keseluruhan, pekerja merasa peran dari pengawas sudah baik, hal ini terlihat dari $90 \%$ lebih pekerja sandblasting yang merasa bahwa pengawas mereka sudah bekerja dengan baik dan benar, dan hanya sebagian pekerja memiliki keluhan karena pengawas jarang memberikan pujian pada mereka, sehingga mereka merasa tertekan karena hanya diberikan hukuman apabila tidak mengikuti peraturan yang ada.

Berdasarkan hasil distribusi jawaban pada faktor promosi kesehatan dan keselamatan kerja, didapatkan hasil bahwa seluruh pekerja menjawab ada slogan atau mading atau spanduk yang mendukung mereka untuk berperilaku aman. Sebanyak $81,8 \%$ pekerja merasa termotivasi dengan adanya media tersebut, sedangkan $18,2 \%$ merasa biasa saja, karena media dirasa pekerja sandblasting kurang menarik. Seluruh pekerja setuju mengenai program tersebut, karena selalu mengingatkan mereka untuk berperilaku aman, dan seluruh pekerja juga mengaku pernah mengikuti pengarahan mengenai peraturan dan bahaya pada lingkungan kerja mereka.

Pada hasil wawancara pada pekerja sandblasting mengenai promosi $\mathrm{K} 3$ pada tempat kerja mereka, didapatkan bahwa $81,8 \%$ pekerja menganggap bahwa promosi $\mathrm{K} 3$ yang dilakukan oleh perusahaan sudah baik, akan tetapi terdapat $18,2 \%$ pekerja yang merasa bahwa media yang digunakan masih kurang menarik.

Hasil penelitian pada faktor ketersediaan APD menurut pekerja mendapatkan bahwa seluruh pekerja menjawab mereka telah disediakan APD yang mendukung keselamatan pekerja di tempat kerja oleh perusahaan dan seluruh pekerja juga merasa bahwa mereka mendapatkan APD tersebut dengan mudah. Selain itu, pada faktor ketersediaan APD ini, sebanyak $100 \%$ pekerja juga setuju bahwa APD yang 
diberikan perusahaan sudah tepat dengan pekerjaan mereka. Sebanyak 90,9\% pekerja mengaku bahwa perusahaan selalu mengganti APD yang sudah tidak layak pakai, akan tetapi $9,1 \%$ pekerja mengatakan bahwa dia sudah mengajukan untuk mengganti APD yang dikenakan karena sudah tidak layak pakai, tapi belum ada respons dari perusahaan sampai penelitian ini dilakukan.

Berdasarkan hasil penelitian dengan kuesioner, $100 \%$ pekerja menganggap bahwa ketersediaan APD oleh perusahaan sudah baik, akan tetapi, ada beberapa pekerja yang merasa bahwa ketersediaan APD masih belum cukup baik karena masih menunggu APD yang tidak layak pakai untuk diganti oleh pihak perusahaan. Ketersediaan APD ini sangatlah penting sebab pekerja sandblasting melakukan proses blasting secara manual dan berada sangat dekat dengan sumber bahaya.

Berdasarkan hasil wawancara pada faktor pelatihan kesehatan dan keselamatan kerja dari sudut pandang pekerja, didapatkan 90,9\% pekerja mengatakan bahwa mereka telah mendapatkan pelatihan untuk mencegah dan menanggulangi kecelakaan, akan tetapi $18,2 \%$ pekerja sisanya mengatakan bahwa mereka belum mendapatkan pelatihan mengenai bahaya kesehatan yang ditimbulkan oleh pekerjaan mereka. Sebanyak 90,9\% pekerja juga mengatakan bahwa mereka telah mendapatkan pelatihan untuk mencegah dan menanggulangi kecelakaan, sedangkan 9,1\% pekerja merasa belum pernah mendapatkan pelatihan tersebut.

Pada wawancara mengenai faktor pelatihan kesehatan dan keselamatan kerja ini, didapatkan bahwa $81,8 \%$ pekerja menjawab bahwa mereka telah diberikan pelatihan mengenai pertolongan pertama pada saat terjadi kecelakaan, sedangkan 18,2\% lainnya mengatakan bahwa mereka belajar dari lomba keselamatan yang diadakan oleh perusahaan, akan tetapi secara keseluruhan, semua pekerja menjawab bahwa pelatihan yang diberikan sudah memenuhi kebutuhan mereka untuk dapat selamat dari pekerjaan yang mereka lakukan.

Menurut hasil distribusi jawaban, didapatkan hasil bahwa 90,9\% pekerja menganggap bahwa pelatihan K3 yang diadakan oleh perusahaan sudah baik, sedangkan 9,1\% sisanya menganggap bahwa pelatihan K3 masih belum cukup baik karena mereka masih tidak mengikuti karena tidak tertarik oleh pelatihan tersebut. Menurut pekerja, dengan seringnya perusahaan mengadakan acara seperti lomba K3 dapat membantu pekerja untuk belajar mengenai beberapa ilmu yang dirasa penting untuk mereka. Hal ini bisa dilakukan agar para pekerja tidak bosan mengikuti pelatihan dan tertarik untuk belajar mengenai keselamatan kerja.

Pada hasil wawancara mengenai faktor peraturan keselamatan dan kesehatan kerja menurut para pekerja sandblasting di PT X, didapatkan hasil bahwa seluruh pekerja sandblasting di PT X mengaku bahwa perusahaan memiliki peraturan mengenai K3 serta pemakaian APD, dan akan mendapatkan sanksi yang tegas apabila melanggar peraturan tersebut, seperti mendapatkan denda sebesar Rp. 50.000,00 per APD yang tidak dipakai. Sebagai contohnya, saat pekerja hanya memakai sepatu sebelah, didenda sebesar Rp. 50.000,00 bila tidak memakai sepatu sama sekali, dikenakan denda sebesar Rp. 100.000,00 bila tidak memakai semua APD, mereka akan dipulangkan kerumahnya. Akan tetapi, saat ditanya mengenai kejelasan peraturan perusahaan $9,1 \%$ responden menjawab kurang mengerti mengenai isi dari peraturan tersebut, sedangkan $90,9 \%$ lainnya menjawab bahwa peraturan dari perusahaan sudah sangat jelas. Sebanyak $90,9 \%$ pekerja merasa sangat termotivasi, karena takut mendapat sanksi, yaitu dipulangkan atau potong gaji dan denda, sedangkan $9.1 \%$ pekerja lainnya merasa bahwa peraturan ini bersifat terlalu menekan pekerja.

Berdasarkan hasil wawancara dengan pihak manajemen, PT X memiliki program pelatihan yang terjadwal, namun tidak memiliki standar operasional prosedur yang jelas dan tertulis mengenai program tersebut sehingga program pelatihan dapat menjadi tidak efektif, selain itu PT X juga melaksanakan program safety induction di mana dalam program tersebut terdapat pengulasan mengenai prosedur kerja aman dan peraturan perusahaan. Pada program safety induction tersebut juga terdapat evaluasi terhadap materi yang telah diulas sepanjang safety induction yang bertujuan untuk memastikan bahwa pekerja yang baru atau pekerja yang baru dimutasi (rolling) telah memahami seluruh materi yang diulas dalam safety induction termasuk prosedur kerja aman.

Pada ketersediaan APD, pihak manajemen mengakui bahwa APD berupa masker hanya diberikan pada pekerja di bagian painting, selain itu pada penggantian safety shoes hanya dilakukan 1 tahun sekali dan melalui proses pendataan pekerja yang tidak mempunyai safety shoes, hal tersebut dilakukan karena pihak manajemen harus melakukan pemesanan terlebih dahulu selain itu pekerja PT X juga masih harus mengeluarkan biaya jika ingin mendapatkan safety shoes. 
Menurut hasil penelitian pada penelitian mengenai identifikasi enabling factors ini, 100\% pekerja menganggap bahwa peraturan K3 yang diadakan oleh perusahaan sudah baik. Pekerja menyarankan, pekerja sebaiknya juga diberikan hadiah atas perilaku mereka, bukan hanya hukuman, karena sifatnya dirasa terlalu menekan pekerja dalam melakukan pekerjaan mereka.

Tabel 1. Distribusi Jumlah Pekerja sandblasting di PT X Berdasarkan Pemakaian APD saat Bekerja

\begin{tabular}{llcc}
\hline \multicolumn{1}{c}{$\begin{array}{c}\text { APD yang } \\
\text { dipakai }\end{array}$} & Komponen penilaian & $\mathbf{n}$ & $\mathbf{\%}$ \\
\hline $\begin{array}{l}\text { Hood } \\
\text { Respirator }\end{array}$ & Memakai & 11 & $100 \%$ \\
\hline Baju & $\begin{array}{l}\text { Memakai lengan } \\
\text { panjang }\end{array}$ & 10 & $90.9 \%$ \\
\cline { 2 - 4 } & $\begin{array}{l}\text { Memakai lengan } \\
\text { pendek }\end{array}$ & 1 & $9.1 \%$ \\
\hline Safety shoes & $\begin{array}{l}\text { Memakai dan kondisi } \\
\text { layak }\end{array}$ & 7 & $63.6 \%$ \\
\cline { 2 - 4 } & $\begin{array}{l}\text { Memakai, kondisi } \\
\text { tidak layak }\end{array}$ & 2 & $18.2 \%$ \\
\cline { 2 - 4 } & $\begin{array}{l}\text { Menggunakan sepatu } \\
\text { lain }\end{array}$ & 2 & $18.2 \%$ \\
\hline Masker & Memakai seadanya & 11 & $100 \%$ \\
\hline
\end{tabular}

Berdasarkan Tabel 1, dapat diketahui bahwa $100 \%$ pekerja sandblasting menggunakan hood respirator untuk memudahkan mereka bekerja di dalam sandblasting chamber. Hasil observasi pada 11 pekerja sandblasting mendapatkan sebanyak $63,6 \%$ pekerja sandblasting memakai safety shoes yang layak pakai, 18,2\% memakai safety shoes yang tidak layak dan $18,2 \%$ tidak memakai safety shoes. Seluruh pekerja sandblasting juga hanya memakai pelindung kepala dari bahan rajutan pada saat bekerja di sandblasting chamber.

Tabel 2. Analisis Hubungan Faktor Pengetahuan dengan Pemakaian APD.

\begin{tabular}{|c|c|c|c|}
\hline \multirow{2}{*}{ Pengetahuan } & \multicolumn{2}{|c|}{ Penggunaan APD } & \multirow{2}{*}{ Total } \\
\hline & Ya & Tidak & \\
\hline Baik & $81.8 \%$ & $9.1 \%$ & $90.9 \%$ \\
\hline Buruk & $9.1 \%$ & $0 \%$ & $9.1 \%$ \\
\hline Total & $90.9 \%$ & $9.1 \%$ & $100 \%$ \\
\hline
\end{tabular}

Berdasarkan Tabel 2 ditemukan bahwa faktor pengetahuan memiliki kuat hubungan dengan perilaku pemakaian APD sebesar 0,100 yang termasuk dalam kategori sangat lemah.
Tabel 3. Analisis Hubungan Faktor Sikap dengan Pemakaian APD

\begin{tabular}{lrlc}
\hline \multirow{2}{*}{ Sikap } & \multicolumn{2}{c}{ Penggunaan APD } & \multirow{2}{*}{ Total } \\
\cline { 2 - 3 } & \multicolumn{1}{c}{ Ya } & Tidak & \\
\hline Baik & $81.8 \%$ & $9.1 \%$ & $90.9 \%$ \\
Buruk & $9.1 \%$ & $0 \%$ & $9.1 \%$ \\
\hline Total & $90.9 \%$ & $9.1 \%$ & $100 \%$ \\
\hline
\end{tabular}

Berdasarkan Tabel 3, ditemukan bahwa faktor sikap memiliki kuat hubungan dengan perilaku pemakaian APD bernilai 0,100 yang termasuk dalam kategori sangat lemah.

Faktor persepsi hanya memiliki 1 kategori, yaitu kategori baik, di mana dalam kategori baik tersebut masih ada $9,09 \%$ pekerja yang berada dalam kategori unsafe. Pada Tabel diatas juga dapat dilihat faktor persepsi hanya terdapat dalam 1 kategori, oleh karena itu faktor persepsi tidak dapat dianalisis menggunakan chi-square. Faktor persepsi 100\% pekerja sudah dalam kategori baik, namun masih ada satu pekerja yang masih tidak memakai Alat Pelindung Diri.

Tabel 4. Analisis Hubungan Faktor Motivasi dengan Pemakaian APD

\begin{tabular}{lccc}
\hline \multirow{2}{*}{ Motivasi } & \multicolumn{2}{c}{ Penggunaan APD } & \multirow{2}{*}{ Total } \\
\cline { 2 - 3 } & Ya & Tidak & \\
\hline Baik & $90.9 \%$ & $0 \%$ & $90.9 \%$ \\
Buruk & $0 \%$ & $9.1 \%$ & $9.1 \%$ \\
\hline Total & $90.9 \%$ & $9.1 \%$ & $100 \%$ \\
\hline
\end{tabular}

Berdasarkan Tabel 4, ditemukan bahwa faktor motivasi memiliki kuat hubungan dengan perilaku pemakaian APD sebesar 0,707 yang termasuk dalam kategori kuat, sehingga dapat dikatakan bahwa faktor motivasi ini memiliki hubungan kuat dengan perilaku pemakaian APD pada pekerja sandblasting di PT X.

Tabel 5. Analisis Hubungan Faktor Peran Rekan Kerja dengan Pemakaian APD.

\begin{tabular}{llll}
\hline \multicolumn{1}{c}{$\begin{array}{c}\text { Peran Rekan } \\
\text { Pekerja }\end{array}$} & \multicolumn{2}{c}{ Penggunaan APD } & Total \\
\cline { 2 - 3 } \multicolumn{1}{c}{ Ya } & \multicolumn{1}{c}{ Tidak } & \\
\hline Baik & $72.8 \%$ & $0 \%$ & $72.8 \%$ \\
Buruk & $18.1 \%$ & $9.1 \%$ & $27.3 \%$ \\
\hline Total & $90.9 \%$ & $9.1 \%$ & $100 \%$ \\
\hline
\end{tabular}

Berdasarkan Tabel 5, ditemukan bahwa faktor peran rekan pekerja memiliki kuat hubungan dengan perilaku pemakaian APD sebesar 0,459 yang termasuk dalam kategori sedang, sehingga dapat dikatakan bahwa faktor peran rekan pekerja 
ini memiliki hubungan sedang dengan perilaku pemakaian APD pada pekerja sandblasting di PT X.

Tabel 6. Analisis Hubungan Faktor Peran Pengawas dengan Pemakaian APD

\begin{tabular}{lrcc}
\hline \multirow{2}{*}{ Peran Pengawas } & \multicolumn{2}{c}{ Penggunaan APD } & \multirow{2}{*}{ Total } \\
\cline { 2 - 3 } & \multicolumn{1}{c}{ Ya } & Tidak & \\
\hline Baik & $81,8 \%$ & $9,1 \%$ & $90,9 \%$ \\
Buruk & $9,1 \%$ & $0 \%$ & $9,1 \%$ \\
\hline Total & $90,9 \%$ & $9,1 \%$ & $100 \%$ \\
\hline
\end{tabular}

Berdasarkan Tabel 6, ditemukan bahwa faktor peran pengawas memiliki kuat hubungan dengan perilaku pemakaian APD sebesar 0,100 yang termasuk dalam kategori sangat lemah, sehingga dapat dikatakan bahwa faktor peran pengawas ini memiliki hubungan sangat lemah dengan perilaku pemakaian APD pada pekerja sandblasting di PT X.

Faktor Promosi K3 hanya terdapat 1 kategori, oleh karena itu faktor promosi K3 tidak dapat dianalisis menggunakan chi-square sehingga hanya dapat ditampilkan dalam bentuk crosstab. Berdasarkan jawaban dari pekerja, promosi K3 di PT X sudah baik, akan tetapi masih ada pekerja yang tidak menghiraukan dan masih tidak memakai APD.

Pada faktor ketersediaan APD hanya terdapat 1 kategori, oleh karena itu faktor ketersediaan APD tidak dapat dianalisis menggunakan chisquare sehingga hanya dapat ditampilkan dalam bentuk crosstab. Seluruh pekerja menjawab bahwa ketersediaan Alat Pelindung Diri di PT X sudah baik, tapi masih ada pekerja yang tidak memakai APD yang telah disediakan oleh perusahaan.

Tabel 7. Analisis Hubungan Faktor Pelatihan K3 dengan Pemakaian APD

\begin{tabular}{|c|c|c|c|}
\hline \multirow{2}{*}{ Pelatihan K3 } & \multicolumn{2}{|c|}{ Penggunaan APD } & \multirow{2}{*}{ Total } \\
\hline & Ya & Tidak & \\
\hline Baik & $81,8 \%$ & $9,1 \%$ & $90,9 \%$ \\
\hline Buruk & $9,1 \%$ & $0 \%$ & $9,1 \%$ \\
\hline Total & $90,9 \%$ & $9,1 \%$ & $100 \%$ \\
\hline
\end{tabular}

Berdasarkan Tabel 7, ditemukan bahwa faktor pelatihan K3 memiliki kuat hubungan dengan perilaku pemakaian APD sebesar 0,100 sehingga dapat dikatakan bahwa faktor pelatihan K3 ini memiliki hubungan sangat lemah dengan perilaku pemakaian APD pada pekerja sandblasting di PT X.

Faktor peraturan K3 hanya terdapat dalam 1 kategori, yaitu kategori baik, di mana dalam kategori baik tersebut masih ada $9,09 \%$ pekerja yang berada dalam kategori unsafe. Pada faktor ini juga dapat dilihat persepsi hanya terdapat 1 kategori, oleh karena itu faktor peraturan $\mathrm{K} 3$ tidak dapat dianalisis menggunakan chi-square sehingga hanya dapat ditampilkan dalam bentuk crosstab. Dari hasil ini dapat disimpulkan bahwa pekerja sandblasting yang mengetahui peraturan K3 di PT X tidak semuanya memakai Alat Pelindung Diri, hal ini dapat terlihat dari adanya satu pekerja yang mengetahui peraturan dengan baik tetapi masih tidak memakai Alat Pelindung Diri.

\section{PEMBAHASAN}

Pengetahuan merupakan hasil "tahu" dan ini terjadi setelah orang melakukan penginderaan terhadap suatu objek tertentu. Penginderaan terjadi melalui panca indra manusia, yakni indra penglihatan, pendengaran, penciuman, rasa dan raba. Sebagian besar pengetahuan manusia diperoleh melalui mata dan telinga (Notoatmodjo, 2007).

Berdasarkan hasil penelitian, pekerja sandblasting di PT X memiliki pengetahuan dalam kategori baik. Pekerja mengetahui dengan jelas mengenai kecelakaan dan keuntungan dari pemakaian alat pelindung diri. Berdasarkan hasil uji statistik dengan menggunakan contingency coefficient, faktor pengetahuan memiliki hubungan yang sangat lemah terhadap perilaku pemakaian APD dengan value sebesar 0,100 , sehingga dapat diartikan bahwa faktor perilaku aman pekerja dalam pemakaian APD hampir tidak memiliki ketergantungan terhadap faktor pengetahuan. Hasil ini diperkuat dengan hasil penelitian dari Halimah (2010) di PT. SIM plant Tambun II yang menyatakan bahwa pengetahuan tidak memiliki hubungan yang bermakna dengan perilaku pemakaian alat pelindung diri.

Sikap belum merupakan suatu tindakan atau aktivitas, akan tetapi merupakan predisposisi tindakan suatu perilaku. Sikap merupakan kesiapan untuk bereaksi terhadap objek di lingkungan tertentu sebagai suatu penghayatan terhadap objek (Notoatmodjo, 2003). Berdasarkan hasil penelitian, pekerja sandblasting di PT X memiliki sikap dalam kategori baik, di mana pekerja menjawab bahwa mereka selalu menggunakan alat pelindung diri yang ditentukan oleh perusahaan.

Berdasarkan hasil uji statistik, faktor sikap memiliki hubungan yang sangat lemah terhadap perilaku pemakaian APD dengan value sebesar 0,100 , sehingga dapat diartikan bahwa faktor perilaku aman 
pekerja dalam pemakaian APD hampir tidak memiliki ketergantungan terhadap faktor sikap.

Persepsi merupakan proses akhir dari pengamatan yang diawali oleh proses pengindraan, yaitu proses diterimanya stimulus oleh alat indra, lalu diteruskan ke otak, dan baru kemudian individu menyadari tentang sesuatu yang dipersepsikan (Sunaryo, 2004). Terdapat dua metode pengukuran persepsi, yaitu metode self report dan involuntary behavior (Sunaryo, 2004).

Menurut hasil penelitian dengan menggunakan metode self report dalam penelitian ini, ditemukan bahwa seluruh pekerja sandblasting di PT X memiliki persepsi dalam kategori baik, di mana pekerja sandblasting merasa pengawas sangat peduli terhadap keselamatan mereka, pelatihan yang diterima pekerja juga sudah sangat sesuai, dan merasa bahwa alat pelindung diri yang mereka pakai sudah memberikan perlindungan yang maksimal. Berdasarkan hasil penelitian ini, faktor persepsi pekerja termasuk dalam kategori baik, dan dikarenakan hasilnya bersifat homogen faktor persepsi ini tidak dapat dianalisis menggunakan uji statistika.

Motivasi adalah pemberian daya penggerak yang menciptakan kegairahan kerja seseorang, agar mereka mau bekerja sama, efektif dan terintegrasi dengan segala upayanya untuk mencapai kepuasan. Motivasi adalah suatu proses di mana kebutuhan mendorong seseorang untuk melakukan serangkaian kegiatan yang mengarah kepada tercapainya suatu tujuan tertentu, atau dapat diartikan sebagai kekuatan atau energi seseorang yang dapat menimbulkan tingkat persistensi dan entusiasmenya dalam melaksanakan suatu kegiatan (Hasibuan, 2005).

Berdasarkan hasil uji statistik dengan menggunakan contingency coefficient, ditemukan bahwa faktor motivasi memiliki hubungan yang kuat dengan value sebesar 0.707 terhadap perilaku pemakaian APD, sehingga dapat diartikan bahwa faktor perilaku aman pekerja sandblasting di PT $\mathrm{X}$ dalam pemakaian APD sangat tergantung pada faktor motivasi.

Peran rekan kerja memiliki peran penting dalam pembentukan perilaku pekerja. Tekanan rekan kerja semakin meningkat saat semakin banyak orang terlibat dalam perilaku tertentu dan saat anggota grup yang berperilaku tertentu terlihat relatif kompeten atau berpengalaman (Geller, 2001).

Berdasarkan hasil uji statistik dengan menggunakan contingency coefficient, faktor peran rekan pekerja memiliki hubungan dalam kategori sedang dengan value sebesar 0.459 , sehingga dapat diartikan bahwa faktor perilaku aman pekerja dalam pemakaian APD memiliki ketergantungan terhadap faktor peran rekan kerja.

Pengawas memiliki posisi kunci dalam mempengaruhi pengetahuan, sikap keterampilan, dan kebiasaan, akan keselamatan setiap karyawan dalam suatu area tanggung jawabnya. Para pengawas mengetahui lebih baik daripada pihak lain mengenai perhatian terhadap individu, catatan cuti, kebiasaan bekerja, perbuatan, keterampilan dalam bekerja. Para pengawas juga memonitor kinerja pekerja, di mana hal ini merupakan sesuatu yang penting untuk kesuksesan program. Pengawasan terhadap aktivitas pekerja diharapkan dapat menumbuhkan kepatuhan dan kesadaran akan pentingnya keselamatan dan kesehatan kerja bagi dirinya, pekerja lain, dan lingkungan kerjanya (Bird dan Germain 1992).

Berdasarkan hasil Berdasarkan hasil uji statistik dengan menggunakan coefficient contingency, ditemukan bahwa faktor peran pengawas memiliki hubungan sangat lemah terhadap perilaku pemakaian APD dengan value sebesar 0.100 , sehingga dapat diartikan bahwa faktor perilaku aman pekerja dalam pemakaian APD hampir tidak memiliki ketergantungan terhadap faktor peran pengawas.

Indra yang paling banyak menyalurkan pengetahuan kedalam otak adalah mata. Kurang lebih $75-87 \%$ dari pengetahuan manusia diperoleh atau disalurkan melalui mata, sedangkan 13-27\% lainnya tersalur melalui indra yang lain (Notoatmodjo 2003). Hal ini dapat disimpulkan bahwa alat visual lebih mempermudah cara penyampaian dan penerimaan informasi. Alat visual dua dimensi adalah berupa gambar, peta, bagan, dan sebagainya. Menurut Elgar Dale dalam Notoatmodjo (2003), diketahui bahwa penyampaian bahan yang hanya dengan kata-kata saja sangat kurang efektif atau intensitasnya paling rendah.

PT X telah menggunakan berbagai media promosi untuk meningkatkan kemampuan mengenali bahaya di tempat kerja dan mencegah penyakit. Media poster dan mading serta berbagai rambu keselamatan dipasang untuk meningkatkan motivasi pekerja. Menurut hasil penelitian, pekerja menganggap bahwa media promosi yang digunakan oleh manajemen PT X sudah cukup baik dan mendorong mereka untuk berperilaku aman. Promosi K3 ini sudah sesuai menurut Germain (1998), bahwa safety promotions atau promosi $\mathrm{K} 3$ adalah suatu bentuk usaha yang dilakukan untuk mendorong dan 
menguatkan kesadaran dan perilaku pekerja tentang K3 sehingga dapat melindungi pekerja, properti, dan lingkungan.

Fasilitas penunjang adalah ketersediaan sarana dan prasaran yang mendukung tindakan pekerja berperilaku selamat dalam bekerja, salah satunya merupakan ketersediaan Alat Pelindung Diri (Suma'mur, 2009). Pengadaan Alat Pelindung Diri sepenuhnya diatur oleh perusahaan dan wajib di terapkan di tempat kerja. Hal ini telah diatur dalam Peraturan Menteri Tenaga Kerja dan Transmigrasi Nomor PER.08/MEN/VII/2010 tentang Alat Pelindung Diri.

Berdasarkan hasil penelitian ditemukan bahwa semua pekerja berpendapat bahwa ketersediaan alat pelindung diri di PT X termasuk dalam kategori baik. Hasil penelitian secara rinci mendapatkan pada ketersediaan APD, pihak manajemen mengakui bahwa APD berupa masker hanya diberikan pada pekerja di bagian painting, selain itu pada penggantian safety shoes hanya dilakukan 1 tahun sekali dan melalui proses pendataan pekerja yang tidak mempunyai safety shoes, hal tersebut dilakukan karena pihak manajemen harus melakukan pemesanan terlebih dahulu selain itu pekerja PT X juga masih harus mengeluarkan biaya jika ingin mendapatkan safety shoes. Peneliti juga menemukan adanya pekerja yang mengajukan penggantian alat pelindung diri yang sudah tidak layak pakai akan tetapi masih belum mendapatkan respons dari pihak manajemen.

Pelatihan adalah suatu cara yang digunakan untuk memberikan atau meningkatkan keterampilan yang dibutuhkan untuk melaksanakan pekerjaan sekarang, sedangkan pendidikan lebih berorientasi kepada masa depan dan lebih menekankan pada peningkatan kemampuan seseorang untuk memahami dan menginterprestasikan pengetahuan (Panggabean, 2004)

Berdasarkan hasil uji statistik, ditemukan bahwa faktor pelatihan K3 memiliki hubungan sangat lemah terhadap perilaku pemakaian APD dengan value sebesar 0.100 , sehingga dapat diartikan bahwa faktor perilaku aman pekerja dalam pemakaian APD hampir tidak memiliki ketergantungan pada faktor pelatihan K3. Hasil penelitian ini diperkuat dengan hasil penelitian Noviandry (2013), yang menyatakan bahwa terdapat hubungan antara pelatihan dengan perilaku pengelas di kota Tangerang pada perilaku pemakaian APD.

PT X telah melaksanakan berbagai pelatihan untuk para pekerjanya, hal ini terlihat dari distribusi jawaban pekerja sandblasting bahwa mereka telah menerima pelatihan mengenai kecelakaan kerja, pelatihan mengenai bahaya kesehatan yang ditimbulkan oleh pekerjaan mereka, pelatihan untuk mencegah dan menanggulangi kecelakaan dan pelatihan mengenai pertolongan pertama pada kecelakaan. Pelatihan ini juga berfungsi sebagai sarana untuk mengingatkan kembali cara bekerja aman pada pekerja dan mengubah perilaku pekerja menjadi perilaku aman (Geller, 2001)

Peraturan merupakan dokumen tertulis yang mendokumentasikan standar, norma, dan kebijakan untuk perilaku yang diharapkan (Geller, 2001). Salah satu strategi perubahan perilaku adalah dengan menggunakan kekuatan dan kekuasaan misalnya peraturan dan undang-undang yang harus dipatuhi oleh anggota masyarakat. Cara ini menghasilkan perubahan perilaku yang cepat, akan tetapi perubahan tersebut belum tentu akan berlangsung lama karena perubahan perilaku yang terjadi tidak atau belum didasari oleh kesadaran sendiri (Notoatmodjo, 2003).

Pekerja sandblasting di PT X mengetahui adanya peraturan mengenai kesehatan dan keselamatan kerja di tempat kerja mereka, dan merasa termotivasi karena takut mendapatkan sanksi, yaitu pemotongan gaji atau dipulangkan. Berdasarkan penelitian lebih rinci, para pekerja merasa tertekan dengan adanya peraturan ini, hal ini dikarenakan mereka tidak mendapatkan reward yang pantas apabila berperilaku aman, akan tetapi diberi hukuman saat tidak melakukan perilaku tersebut.

\section{SIMPULAN}

Berdasarkan hasil penelitian, analisis data, dan pembahasan yang telah dilakukan, maka dapat diambil kesimpulan bahwa identifikasi faktor penentu perilaku antara lain, predisposing factors terdiri atas pengetahuan, sikap, persepsi dan motivasi pekerja. Pengetahuan pekerja di PT X sebesar 90,9\% termasuk dalam kategori baik. Sikap pekerja pada PT X sebesar 90,9\% termasuk dalam kategori baik. Persepsi pekerja pada PT Bangun Sarana Baja sebesar $100 \%$ termasuk dalam kategori baik, dan motivasi pekerja pada PT X sebesar $90.9 \%$ termasuk dalam kategori baik. Reinforcing factors yang terdiri atas peran rekan kerja dan peran pengawas. Peran rekan kerja pada pekerja sandblasting di PT X sebesar $72,7 \%$ termasuk dalam kategori baik, sedangkan faktor peran pengawas pada pekerja sandblasting di PT X sebesar 90,9\% termasuk dalam kategori baik. 
Enabling factors yang terdiri atas promosi K3, ketersediaan APD, Pelatihan K3, dan Peraturan K3. Faktor promosi K3 pada pekerja sandblasting di PT X sebesar $100 \%$ termasuk dalam kategori baik. Faktor ketersediaan APD pada pekerja sandblasting di PT X sebesar 100\% termasuk dalam kategori baik. Faktor pelatihan K3 pada pekerja sandblasting di PT X sebesar 90,9\% termasuk dalam kategori baik, dan faktor peraturan $\mathrm{K} 3$ pada pekerja sandblasting di PT X sebesar $100 \%$ termasuk dalam kategori baik. Perilaku pemakaian APD pada 90.9\% pekerja sandblasting di PT X termasuk dalam kategori safe.

Hubungan predisposing factors dengan pemakaian APD pada pekerja sandblasting di PT $\mathrm{X}$ adalah faktor pengetahuan memiliki hubungan yang sangat lemah dengan faktor pemakaian APD, faktor sikap memiliki hubungan yang sangat lemah dengan faktor pemakaian APD, faktor persepsi pekerja $100 \%$ berada dalam kategori baik, faktor motivasi memiliki hubungan yang kuat dengan factor pemakaian APD.

Hubungan reinforcing factors dengan pemakaian APD pada pekerja sandblasting di PT X adalah faktor peran rekan kerja memiliki hubungan dalam kategori sedang dengan faktor pemakaian APD, faktor pengawas memiliki hubungan yang sangat lemah dengan faktor pemakaian APD.

Hubungan enabling factors dengan pemakaian APD pada pekerja sandblasting di PT X adalah sebagai berikut, faktor promosi K3 pekerja sandblasting di PT X 100\% termasuk dalam kategori baik, faktor ketersediaan APD pekerja sandblasting di PT X 100\% termasuk dalam kategori baik, faktor pelatihan K3 memiliki hubungan yang sangat lemah dengan factor pemakaian APD, faktor peraturan K3 pekerja sandblasting di PT X 100\% termasuk dalam kategori baik.

\section{DAFTAR PUSTAKA}

Bird, E.F., and Germain, G.L. 1992. Practical Loss Control Leadership. Edisi Revisi. USA: Division Of International Loss Control Institute.

Geer, L.A., Curbow, B.A., Anna, D.H., Lees, P. S.J., Buckley, T.J. 2006. Development of a
Questionnaire To Assess Worker Knowledge, Attitudes and Perceptions Underlying Dermal Exposure. Scandinavian Journal of Work, Environment \& Health

Geller, E.S. 2001. The Psychology of Safety Handbook. USA: Lewis Publisher.

Germain, G.L. 1998. Safety Health Environmental Management "Practitioners Guide". International Risk Management Institute Inc.

Green, L.W. 1991. Health Education Planning, a Diagnostic Approach. California: Mayfield Publishing Company.

Halimah, S. 2010. Faktor yang Mempengaruhi Perilaku Aman Karyawan Di PT. SIM Plant Tambun II. Skripsi. Jakarta: UIN.

Handoko, H. 2001. Managemen Personalia dan Sumber daya Manusia Edisi 2. Yogyakarta: BPFE Fakultas Ekonomi UGM.

Hasibuan, M.S.P. 2005. Manajemen Sumber Daya Manusia, Edisi Revisi. Jakarta: Bumi Aksara.

Ikhsan, M. 2002. Penatalaksanaan Penyakit Paru Akibat Kerja. Jakarta: UI Press.

Notoatmodjo, S. 2003. Pendidikan dan Perilaku Kesehatan. Jakarta: PT. Rineka Cipta.

Notoatmodjo, S. 2007. Kesehatan Masyarakat Ilmu dan Seni, Jakarta: PT Rineka Cipta.

Noviandry, I. 2013. Faktor-faktor yang Berhubungan dengan Perilaku Pekerja dalam Penggunaan Alat Pelindung Diri (APD) Industri Pengelasan Informal di Kelurahan Gondrong, Kecamatan Cipondoh, Kota Tangerang Tahun 2013. Skripsi. Jakarta: UIN Syarif Hidayatullah.

Panggabean, S.M. 2004. Manajemen Sumber Daya Manusia. Bogor: Ghalia Indonesia.

Sugiono. 2004. Statistika untuk Penelitian Cetakan Keenam. Bandung: Penerbit Alfabeta.

Suma'mur. 2009. Higiene Perusahaan dan Kesehatan Kerja (Hiperkes). Jakarta: CV Sagung.

Sunaryo. 2004. Psikologi Untuk Keperawatan. Jakarta: EGC.

Susanto, A.D. 2011. Pneumokoniosis. Jurnal. Jakarta: Departemen Pulmonologi dan Ilmu Kedokteran Respirasi Fakultas Kedokteran Universitas Indonesia Rumah Sakit Persahabatan. 